\title{
Intracellular proteolysis in Atlantic salmon Salmo salar fingerlings ( $0+$ ) from different biotopes in an Arctic river (Varzuga River, White Sea Basin)
}

\author{
Nina N. Nemova, Elena I. Kaivarainen, Marina Y. Krupnova, \\ Aleksey E. Veselov and Svetlana A. Murzina \\ Institute of Biology, Karelian Research Centre of the Russian Academy of Sciences, 11 \\ Pushkinskaya Street, Petrozavodsk 185910, Russia (nemova@krc.karelia.ru)
}

\section{Dmitry S. Pavlov}

A.N. Severtsov Institute of Ecology and Evolution, Russian Academy of Sciences, 33 Leninskij prosp., Moscow, 119071, Russia

\author{
Received June 2016; first published online 30 January 2017
}

ABSTRACT. The activity of intracellular proteolytic enzymes was studied in Atlantic salmon (Salmo salar L.) fingerlings $(0+)$ after hatching from spawning nests and dispersal in the Varzuga River main stem and its Pyatka tributary (Kola Peninsula, White Sea Basin). The study focused on calcium-dependent cytosolic proteinases ( $\mu$ - and m-calpains), lysosomal proteinases (cathepsins B and D) and collagenase, and determined the free/protein-bound hydroxyproline ratio, which portrays collagenolytic activity. Compared to fingerlings from the Varzuga main stem, the intracellular proteolytic enzyme activity of cysteine proteinase and collagenase was higher in fingerlings from the Pyatka tributary, where current velocities and food availability were higher. These results indicate that there is a higher rate of intracellular protein metabolism in the juveniles from this phenotypic group.

\section{Introduction}

In northern Europe, the world's largest stock of Atlantic salmon (Salmo salar L.) reproduces in several large rivers, including the Varzuga River. The Varzuga River is a large polar river in the White Sea Basin and has one of the largest breeding populations of Atlantic salmon. In the last century, 50,000-130,000 salmonids spawned annually in this river (Kazakov and others 1992). The hydrology of the main stem and tributaries of the Varzuga River is distinct from other rivers. There are numerous rapids and shoals located along the river, presenting spawning and nursery areas for salmonids (Veselov and Kalyuzhin 2001). Heterogeneity in the size, mass and volume of the accumulated stores of salmon eggs determine the growth rates and normal development of the fish. This heterogeneity also results in unequal abilities of the larvae to resettle in different microbiotopes, mainly regulated by rheotactic behaviour. Rheotaxis compensates for the drift of fish downstream and promotes their retention in a habitat (Veselov and others 1998). Intrapopulational heterogeneity can form in an environment and can even occur among the offspring of one pair of producers (Pavlov and others 2007). The biological significance of this heterogeneity is that it increases larval survival at the early stages of ontogenesis. Embryogenesis culminates in the Varzuga River main stem. Post-embryonic development involves the dispersal of the fry from these nests and foraging along the coast of the main stem and in tributaries. Differences in the hydrological regimes and availability of food in these habitats results in the differentiation of two phenotypic groups (Veselov and others 2005) with distinct biochemical parameters of energy metabolism (Pavlov and others 2007, 2008).

Since the growth rate, locomotor activity and availability of energy substrates in fish depend on the rate of protein degradation in skeletal muscle, which accounts for up to $25 \%$ of all protein in muscle tissue of salmon (Mommsen 2001, 2004; Johnston and others 2011), the potential differences in intracellular proteolytic enzyme activity between salmon fingerlings are interesting. There are three known key systems of protein degradation in vertebrates: ubiquitin-proteasome, lysosomal-autophagic and calpain. The proteasome and lysosomal pathways dominate mammalian systems (Sandri 2010). In contrast, the lysosomal and calpain systems dominate in fish (Mommsen 2004; Salem and others 2005, 2006; Seiliez and others 2012, 2014).

Another essential factor for the growth and development of an organism is the proteolysis of connecting tissue in the extracellular matrix, primarily the hydrolysis of collagen, which accounts for approximately $25 \%$ of all protein in an organism. The rate of collagen metabolism can be measured by the collagenolytic activity (a matrix metalloproteinase) and by the level of free and proteinbound hydroxyproline (an amino acid unique to collagen) (Jaescke 1975; Reddy and Enwemeka 1996; Torrissen 2014).

The aim of this study was to perform a comparative analysis of the intracellular proteolysis indices in two groups of Atlantic salmon fingerlings $(0+)$ after distribution from their spawning places to biotopes with different conditions, that is, along the coast of the Varguza River main stem and in the Pyatka tributary. 


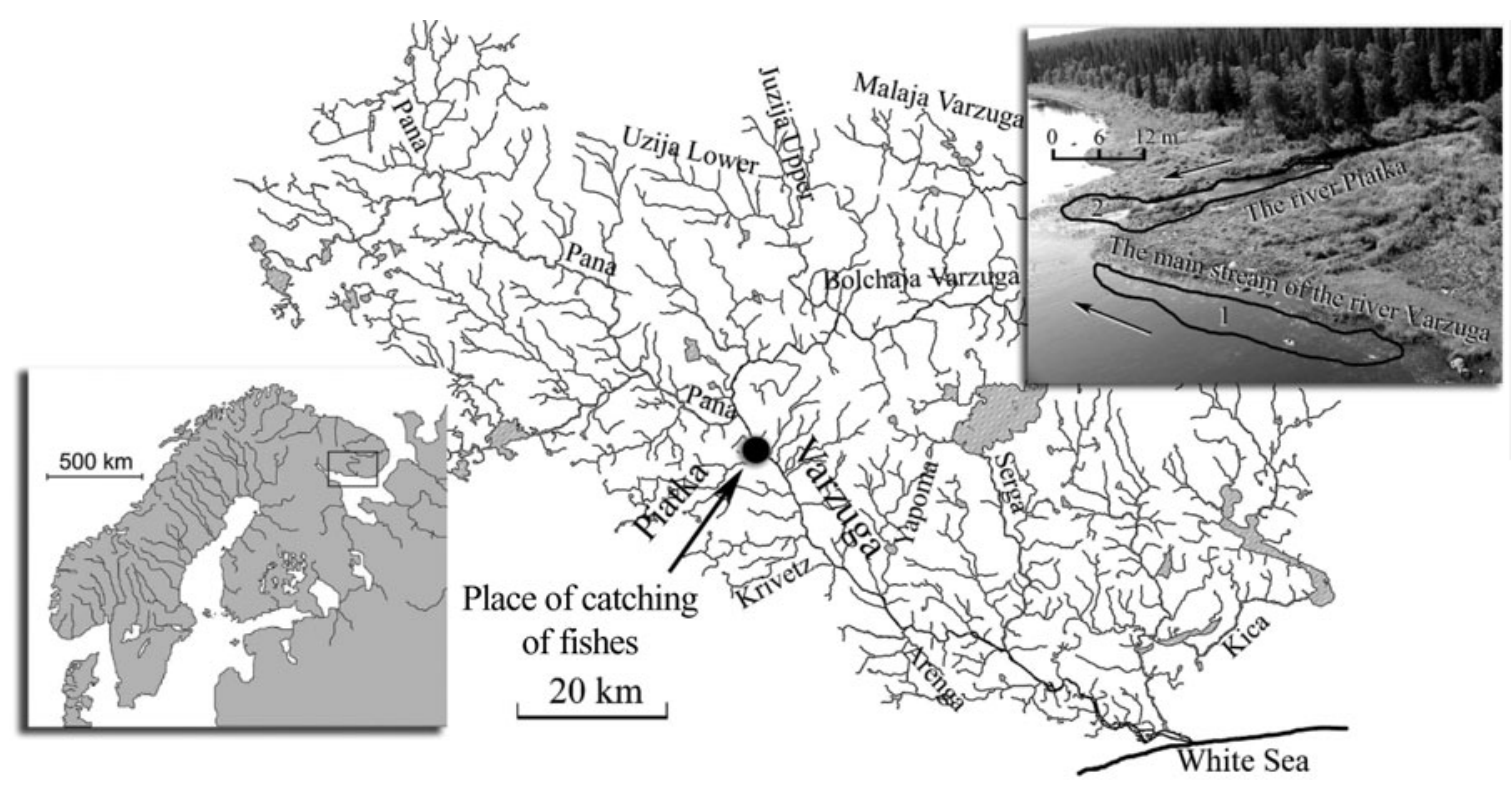

Fig. 1. The Varzuga River and sampling areas of Atlantic salmon fingerlings in the Varzuga main stem (1) and the Pyatka tributary (2).

\section{Materials and methods}

\section{Ichthyological methods}

We have previously determined (Veselov and others 2005) that Atlantic salmon annually spawned in the Varzuga River's main stem, where 8-12 nests built by several different females remained in autumn. The nests were found in sites $0.8-0.9 \mathrm{~m}$ deep, where current velocities at the surface were $0.8 \mathrm{~m} / \mathrm{sec}$. Current velocities were measured with a custom-constructed hydrologic whirligig (screw diameter $10 \mathrm{~mm}$ with a measuring range of $0.01-$ $1.5 \mathrm{~m} / \mathrm{sec}$ ). No spawning took place in the downstream regions of the river. This finding, coupled with early spring electrofishing and underwater observations, suggests that after depleting the yolk sac and leaving the nests in the main stem, young salmon dispersed into different tributaries. Such tributaries are commonly small, with widths of 3-6 m and water consumption levels $<1.5$ $\mathrm{m}^{3} / \mathrm{s}$, and they flow into rapids and shoals of the main stem of the river (Veselov and Kalyuzhin 2001). To study the differences between phenotypic groups, we chose the Pyatka tributary (Fig. 1, site 2), which flows into a spawning site in the main stem (Fig. 1, site 1). By the time the fingerlings occupied these biotopes, they had gained scales and juvenile colouring, signifying the end of the larval stage and the beginning of the fry stage.

Atlantic salmon fingerlings were collected with an electrofishing device designed for research purposes (Norway, Fa-2) (Zippin 1956). Samples were collected twice; first, on 15 June 2007, soon after the fry had reached the coastline and the tributary mouth, and then on 30 July 2007. To eliminate electroshock stress, the collected fish were held for $24 \mathrm{~h}$ in cages located in the main stem of the river. Length and weight measurements were taken for each fish. The sampled biological material (120 specimens from each biotope) was then frozen in situ in liquid nitrogen and delivered to the laboratory for biochemical analysis.

\section{Biochemical methods}

Intracellular proteolytic enzyme and collagenolytic activity were determined individually $(n=25-30)$ in whole organisms. Calpain activity was measured in composite samples from $8-10$ specimens ( $5 \mathrm{~g}$ aliquots, $n=5$ ), as it involved chromatographic separation of tissue proteins.

Quantitative analysis of soluble protein levels in tissues (mg/g tissue) was performed based on the method from Bradford (1976), with bovine serum albumin as the standard. Standard assays for proteolytic activity in animal tissues, including ectothermic tissues, enabled the estimation of maximal proteolytic (or peptidase) activity under standardised conditions.

\section{Lysosomal proteinase activity}

Cysteine proteinase cathepsin B and aspartic cathepsin $\mathrm{D}$ are the main proteinases of lysosomes (Bohley 1987). After homogenising with an Ultra-Turrax homogeniser, the samples were mixed $1: 10$ with a $0.25 \mathrm{M}$ sucrose solution with $0.01 \%$ Triton X-100 (Merck) (1,200 rpm, $60 \mathrm{sec}$ ) and centrifuged (30 min, 10,000 g; Allegra 64R Beckman Coulter). Cathepsin B (EC 3.4.22.1) activity in the supernatant fraction was determined by the digestion of $0.065 \mathrm{M}$ N-benzoyl-L-arginine ethyl ester $\mathrm{HCl}$ solution in $0.1 \mathrm{M}$ acetate buffer ( $\mathrm{pH}$ 5.0) (Matsuda and Misaka 1974), and cathepsin D (EC 3.4.23.5) activity was determined using $1 \%$ bovine haemoglobin hydrolysis in 0.1 M acetate buffer ( $\mathrm{pH}$ 3.6) following a modified Anson method (Barrett and Heath 1977). The activity of cathepsin B and D (activity units) was expressed as units of change in optical absorption ( $\mathrm{E}_{525}$ and $\mathrm{E}_{280}$, respectively) per $1 \mathrm{mg}$ protein per $1 \mathrm{~h}$ incubation at $37^{\circ} \mathrm{C}$. 
Activity of calcium-dependent proteinases

The samples were homogenised with an Ultra-Turrax homogeniser in $20 \mathrm{mM}$ Tris- $\mathrm{HCl}$ buffer ( $\mathrm{pH} 7.5$ ) with $80 \mathrm{mM} \mathrm{KCl}, 5 \mathrm{mM} \mathrm{Na}$-EDTA and $20 \mathrm{mM}$ dithiothreitol in a $1: 3$ ratio $(\mathrm{w} / \mathrm{v})$ and centrifuged $\left(4^{\circ} \mathrm{C}, 20,000 \mathrm{rpm}\right.$, $15 \mathrm{~min}$ ); then, the supernatant (soluble fraction) was applied to a $2.5 \times 95 \mathrm{~cm}$ column with Sephacryl S-300 (Pharmacia) equilibrated with $10 \mathrm{mM}$ Tris- $\mathrm{HCl}$ buffer ( $\mathrm{pH} 7.5$ ) containing $50 \mathrm{mM} \mathrm{NaCl}, 4 \mathrm{mM}$ EDTA and $5 \mathrm{mM}$ mercaptoethanol. Chromatographic separation of the samples enabled the isolation of a calpain-specific inhibitor, calpastatin, and the fractionation of individual molecular forms of the enzyme. Separation was made at $4^{\circ} \mathrm{C}$ using standard LKB-Pharmacia devices. Fractions were recorded on a Uvicord II absorptiometer at $280 \mathrm{~nm}$. The activity of calpains (EC 3.4.22.17), calcium-induced activity, was determined in $4 \mathrm{ml}$ eluent fractions using a standard technique of casein hydrolysis (Murachi and others 1981). The reaction mixture for calpain activity determinations was a $2.5 \mathrm{ml}$ total volume containing $0.4 \%$ casein, $5 \mathrm{mM}$ dithiothreitol, $50 \mathrm{mM}$ imidazole-HC1 buffer (pH 7.5) and enzyme solution. Experimental samples were incubated in the presence of $\mathrm{CaCl}_{2}$ solutions (at $\mu \mathrm{M}$ and $\mathrm{mM}$ concentrations) and calcium was added to control samples after incubation. After a $30 \mathrm{~min}$ incubation at $30^{\circ} \mathrm{C}$, the reaction was terminated by adding an equal volume of $10 \%$ trichloroacetic acid. The concentration of acid-soluble hydrolysis products was determined by spectrophotometry $\left(E_{280}\right)$. Calpain activity units were defined as the change in optical density $\left(E_{280}\right)$ over a 30 min incubation and taken as $1 \mathrm{IU}$. After chromatographic separation of the salmon fingerling homogenates, fish calpains with $\mu \mathrm{M}$ and $\mathrm{mM}$ sensitivity to calcium were detected, which can be identified as homologues of mammalian $\mu$-calpain and m-calpain (Salem and others 2005; Bondareva and others 2006).

Three distinct protein fractions exhibiting calciumdependent proteolytic activity and differing in calcium sensitivity were identified in salmon fingerling homogenates (Nemova and others 2014). Fish calpains with $\mu \mathrm{M}$ and $\mathrm{mM}$ calcium sensitivity can be identified as homologues of mammalian $\mu$-calpain and m-calpain, respectively, and the low-molecular component is a catalytically active subunit of the named calpains (Sorimachi and Suzuki 2001; Bondareva and others 2006).

\section{Determination of collagenase (EC 3.4.24.3) activity}

The method for determining enzyme activity was based on the incubation of enzyme-containing biological fluid with collagen followed by a hydroxyproline-based determination of the protein degradation products (Jaescke 1975; Reddy and Enwemeka 1996). Units of enzyme activity were defined as the amount in $1 \mathrm{~g}$ wet weight resulting in the release of $1 \mu \mathrm{M}$ hydroxyproline.

Determination of free and protein-bound hydroxyproline Quantitative determinations of free and protein-bound hydroxyproline were based on conventional techniques
(Jaescke 1975; Reddy and Enwemeka 1996). The material was fixed with ethanol in a 1:10 ratio. The fixed material was centrifuged at 4,000 $\mathrm{g}$ for $15 \mathrm{~min}$. The supernatant fraction was removed and the pellet was rinsed with $5 \mathrm{ml}$ of $80 \%$ ethanol and centrifuged using the same settings. The resulting extract was dried in a water bath and the dry residue containing free hydroxyproline was dissolved in $1 \mathrm{ml}$ of $10 \%$ isopropanol. To isolate proteinbound hydroxyproline, the dry residues of fish tissues were hydrolysed in vacuum sealed ampoules with $6 \mathrm{~N} \mathrm{HCl}$ for $24 \mathrm{~h}$ at $105^{\circ} \mathrm{C}$ after the extraction of free amino acids. The hydrolysate was filtered and the filtrate was dried in a water bath. The $\mathrm{HCl}$ was removed by repeatedly (5-6 times) dissolving the dry residue in water and evaporating, after which the dry residue was dissolved in $1 \mathrm{ml}$ of $10 \%$ isopropanol. Hydroxyproline levels ( $\mu \mathrm{M} / \mathrm{g}$ tissue) were calculated using a calibration curve based on the standard dilutions of hydroxyproline.

\section{Statistical treatment of the results}

To compare groups, a non-parametric Mann-Whitney $U$ test was used for parameters without normal distribution, such as proteinase activity and hydroxyproline content. The data were analysed to determine whether they exhibited a normal distribution using the StatGraphics package and Excel.

\section{Results}

\section{Fingerling dispersal and formation of phenotypic heterogeneity}

Fingerlings $(0+)$ dispersed from the nests to the Pyatka tributary and the littoral zone of the Varzuga River main stem in June at high water when temperatures reached $\geq$ $12^{\circ} \mathrm{C}$. This process lasted $6-8$ days. Fingerlings moved from the nursery area to the main stem surface and were then carried downstream by the current.

The hydrological regime in the dispersal areas changed daily as the water level in the Varzuga River lifted by 9-10 $\mathrm{cm}$ per day, reducing flow velocities and causing multiple streams to form between large exposed boulders. A daily 5-6 cm decline in water level also occurred in the tributary, affecting the power of the current. As a result, young salmon that moved earlier mostly reached the tributary, whereas those dispersing several days later settled along the main stem littoral biotopes. Fish larvae have an innate rheotactic behavioural response to the current (Pavlov 1979; Veselov and others 1998) and move actively against the direction of the current along the littoral zone of the main stem to tributaries. Over the course of two weeks after resettlement, the water level and current flow rate significantly decreased in both the main stem and in the tributary. As a result, the fingerlings in both the tributary and the main stem were sedentary and no migration of larvae between the main stem of the river and the tributary was observed.

As previous studies have shown, the temperature of the water was higher in the Pyatka tributary than in the main 
Table 1. Characteristics of salmon fingerlings and the biotopes in the Varzuga main stem and the Pyatka tributary.

\begin{tabular}{|c|c|c|}
\hline Characteristic & Varzuga main stem & Pyatka tributary \\
\hline \multicolumn{3}{|l|}{ Body length (AC), cm } \\
\hline 15 June 2007 & $2.22 \pm 0.04$ & $2.28 \pm 0.04$ \\
\hline 30 July 2007 & $4.00 \pm 0.20$ & $4.30 \pm 0.20$ \\
\hline \multicolumn{3}{|l|}{ Body weight, $\mathrm{g}$} \\
\hline 15 June 2007 & $0.26 \pm 0.04$ & $0.27 \pm 0.05$ \\
\hline 30 July 2007 & $0.43 \pm 0.03^{*}$ & $0.63 \pm 0.03^{*}$ \\
\hline Fry density, ind. $/ \mathrm{m}^{2}$ & $1-3$ & $4-5$ \\
\hline Depth, $m$ & $0.15-0.45$ & $0.10-0.30$ \\
\hline Flow velocity at water surface, $\mathrm{m} / \mathrm{sec}$ & $0.4-0.7$ & $0.7-1.0$ \\
\hline $\begin{array}{l}\text { Food capacity }{ }^{\mathrm{a}} \text {, weight of invertebrates } \\
\text { from } 1 \mathrm{~m}^{2} \text { of bottom }\end{array}$ & Low: $<2 \mathrm{~g} / \mathrm{m}^{2}$ & High: $>10 \mathrm{~g} / \mathrm{m}^{2}$ \\
\hline $\begin{array}{l}\text { Type of ground fractions of the } \\
\text { riverbed }\end{array}$ & $\begin{array}{l}\text { Gravel, insufficient } \\
\text { shelter }\end{array}$ & $\begin{array}{l}\text { Bouldery gravel, } \\
\text { unlimited shelter }\end{array}$ \\
\hline \multicolumn{3}{|l|}{ Size fractions of riverbed ${ }^{b}, \%$} \\
\hline Sand $(<0.25 \mathrm{~cm})$ & $5 \%$ & $3 \%$ \\
\hline Gravel $(0.26-0.5 \mathrm{~cm})$ & $6 \%$ & $3 \%$ \\
\hline Fine pebble $(0.6-1.5 \mathrm{~cm})$ & $9 \%$ & $5 \%$ \\
\hline Medium pebble (1.6-2.5 cm) & $18 \%$ & $7 \%$ \\
\hline Coarse pebble $(2.6-5.0 \mathrm{~cm})$ & $33 \%$ & $13 \%$ \\
\hline Small boulder $(5.1-10.0 \mathrm{~cm})$ & $14 \%$ & $39 \%$ \\
\hline Medium boulder $(11-25 \mathrm{~cm})$ & $11 \%$ & $17 \%$ \\
\hline Large boulder $(26-50 \mathrm{~cm})$ & $3 \%$ & $12 \%$ \\
\hline Very large boulder (>51 cm) & $1 \%$ & $1 \%$ \\
\hline Water temperature, ${ }^{\circ} \mathrm{C}$ & 17.2 & 18.7 \\
\hline
\end{tabular}

main stem*Differences reliable at $P \leq 0.05$.

${ }^{a}$ After Shustov 1983.

${ }^{\mathrm{b}}$ After Veselov and Kalyuzhin 2001.

stem during the day, whereas at night, the opposite was observed. In the tributary, the temperature fluctuated by 5$6^{\circ} \mathrm{C}$ during the day whereas in the main stem, temperature fluctuations were around $2-3^{\circ} \mathrm{C}$ during the day in June.

It has been shown that for young salmon $(0+)$ the foraging conditions are more favourable in the small tributaries of the Varzuga River compared with the main stem (Baryshev and others 2005). Some of the characteristics of the biotopes inhabited by the salmon fingerlings are presented in Table 1. Fingerlings from the Pyatka tributary inhabited areas with higher flow velocity $(0.6-0.9 \mathrm{~m} / \mathrm{sec}$ versus $0.4-0.7 \mathrm{~m} / \mathrm{sec})$ and made more darts for food $(23$ \pm 3 in 15 min versus $14 \pm 5$ in 15 min; calculated by AEV during underwater observations) during the day in sunny weather compared to juveniles in the main stem. Fish density in the tributary was twofold higher (Table 1) due to favourable foraging conditions in the biotope. Larger areas of exposed ground contribute to greater isolation of fingerlings from each other, resulting in decreased competition. Higher current flow rates in the tributaries mean they are richer sources of food. Daily temperature oscillations and good foraging conditions can advance the growth of juveniles in the tributaries compared with those in the main stem (Konstantinov and others 2007).

The first sampling effort was made soon after the emergence of fry from spawning nests (15 June 2007). In these samples, the length and weight measurements of fish were similar between the two biotopes (Table 1). In
July, the fingerlings collected from the Pyatka tributary had higher body weight (1.5-fold) compared with fish from the main stem.

\section{Activity of proteolytic enzymes}

The results of the analysis of selected proteolytic enzyme activity and soluble protein content in salmon fingerlings from the different biotopes of the Varzuga River are presented in Table 2.

The soluble protein content in young salmon was not significantly different between the Pyatka tributary and the Varzuga main stem. The activity of most of all intracellular proteolytic enzymes studied was significantly higher in the fingerlings from the Pyatka tributary compared with the fish from the main stem. However, lysosomal aspartic proteinase cathepsin D activity was not significantly different between the biotopes.

The fingerlings from the Pyatka tributary had approximately 1.3 -fold higher total activity of calciumdependent proteinases, mainly due to a higher (5.7-fold) activity of m-calpain, which depends on $\mathrm{mM}$ concentrations of calcium. The activity of lysosomal cysteine proteinase cathepsin B in fingerlings from the Pyatka tributary was also significantly higher (1.3-fold) than in fish from the main stem.

The fingerlings from the studied biotopes also differed significantly in the level of collagenolytic activity. Collagenase activity in fish from the Pyatka tributary was 
Table 2. Activity of proteolytic enzymes and protein content in salmon fingerlings from the Varzuga main stem and the Pyatka tributary $(n=25-30)$.

\begin{tabular}{|lcc|}
\hline & \multicolumn{2}{c|}{ Biotope } \\
\cline { 2 - 3 } Variable & Varzuga main stem & Pyatka tributary \\
\hline Protein concentration (mg/g tissue) & $43 \pm 0.6$ & $48 \pm 0.8$ \\
Total calpain activity (activity units) & $0.22 \pm 0.01$ & $0.47 \pm 0.02^{*}$ \\
$\mu$-calpain activity (activity units) & $0.15 \pm 0.01$ & $0.07 \pm 0.01^{*}$ \\
m-calpain activity (activity units) & $0.07 \pm 0.01$ & $0.40 \pm 0.03^{*}$ \\
Cathepsin D activity (activity units) & $5.60 \pm 0.4$ & $5.35 \pm 0.4$ \\
Cathepsin B activity (activity units) & $42.10 \pm 2.0$ & $55.50 \pm 2.5^{*}$ \\
Free hydroxyproline ( $\mu \mathrm{M} / \mathrm{g}$ tissue) & $80.90 \pm 6.2$ & $118.10 \pm 7.8^{*}$ \\
Protein-bound hydroxyproline $(\mu \mathrm{M} / \mathrm{g}$ tissue) & $1260.50 \pm 90.5$ & $246.20 \pm 20.7^{*}$ \\
Collagenolytic activity (activity units) & $0.08 \pm 0.01$ & $0.16 \pm 0.01^{*}$ \\
\hline
\end{tabular}

${ }^{*} P \leq 0.05$.

1.3-fold higher compared with fish from the Varzuga main stem. In the fingerlings from the main stem, levels of protein-bound hydroxyproline were fivefold lower and levels of free hydroxyproline were twofold higher than in the fish from the Pyatka tributary.

\section{Discussion}

Salmonids have a complex life cycle including different developmental stages maintained by a complex system of adaptations. Significant morphological and physiological changes during ontogenesis, as prerequisites of future smoltification, occur when fish inhabit river sites. It was shown in this study that salmon fingerlings (at $0+$ age) resettle and inhabit different biotopes of the main channel of the river and its tributaries (including the Pyatka tributary) after hatching. Differences in the hydrologic and foraging conditions between the main stem and the tributary lead to the formation of two phenotypic groups and determine the further differentiation of juveniles. The foundation for these processes is significant changes in cell metabolism. Intensive proteolysis at an early stage of post-embryonic development, when young fish are adapting to the external environment, is very important for active growth and further development in salmon (Overturf and Gaylord 2009; Valente and others 2013; Lysenko and others 2015). Differences in the activity of intracellular proteolytic enzymes in salmon fingerlings from biotopes with distinct ecological conditions support the above statement. The elevated activity of cysteine proteinases $\mathrm{m}$-calpain and cathepsin $\mathrm{B}$, which have a central role in regulating limited proteolysis (Attaix and others 1999), indicates a high rate of protein metabolism in the fingerlings from the Pyatka tributary. Moreover, protein metabolism has two components: protein synthesis and degradation. Limited proteolysis plays an important role in the post-translational processing of synthesised proteins. The correlation between $\mathrm{m}$-calpain and cathepsin B may be due to calcium homeostasis. For example, Mizote and others (1999) demonstrated that cathepsin $\mathrm{B}$ in Xenopus eggs promotes intracellular $\mathrm{Ca}^{2+}$ release from endoplasmic reticulum calcium stores, increasing the concentration of cytoplasmic $\mathrm{Ca}^{2+}$, which is considered to be an activator of calpains.

Increased activity of calpains may be associated with higher levels of ionised cytoplasmic calcium in the cytoplasm of cells, as well as with a higher content of membrane cholesterol and certain phospholipids, which could act as direct regulators of calpain activity in the cell (Tompa and others 2001; Lysenko and Nemova 2012; Murzina and others 2014). Increased activity of calciumdependent proteolytic activity, mainly of m-calpain (5.7fold), in fingerlings from the Pyatka tributary was correlated with a higher locomotor activity of juveniles based on calcium homeostasis in muscles. Higher locomotor activity of an organism is known to be closely associated with muscle tissue calcium homeostasis (Cottin and others 1994; Seebacher and others 2012).

Studies of the biochemical parameters of collagen metabolism in young salmon $(0+)$ showed that individuals from the Pyatka tributary had higher collagenase activity and free hydroxyproline content (with a simultaneous reduction in protein-bound hydroxyproline) compared with fish from the Varzuga main stem, indicating a relatively higher rate of collagen metabolism in the former group. The functions of collagen are diverse as it supports the specific structure of organs and tissues during the development and life cycle of an organism. Collagen, like other proteins, is subjected to catabolic and anabolic processes. Catabolised collagen provides energy and catabolites, and thus a continuous metabolism. We assume that our findings, higher collagenase activity and changes in the ratio of free hydroxyproline to protein-bound hydroxyproline found in juveniles from the Pyatka tributary, reflects the role of these proteins in the metabolism of connective tissue during the growth and development of young salmon. Furthermore, in addition to specific collagenases, collagenolysis is thought to involve lysosomal proteinases (Eherington and Evans 1977), which is supported by our data showing elevated collagenolytic and lysosomal proteinase cathepsin B activity in fingerlings from the Pyatka tributary. Thus, we have demonstrated a relationship between the functional activity of the selected enzymes and intracellular proteolysis. 
The environmental conditions in the biotopes we studied had less effect on the activity of lysosomal aspartic proteinase cathepsin $\mathrm{D}$ in the fingerlings. It may be that anabolism dominates over catabolism during the studied period of early post-embryogenesis in young fish. Bohley (1987) proposed that the principal function of cathepsin D is complete proteolysis of protein molecules into dipeptides and amino acids. It is possible that changes in the activity of the lysosomal endopeptidase would be found in the next stages of development of juveniles, when degradation processes prevail over synthesis.

\section{Conclusion}

The ecological conditions along the main stem coast and in a tributary of the Arctic Varzuga River contribute to the differentiation of Atlantic salmon fingerlings and the formation of two phenotypic groups. We assume that more favourable hydrologic conditions in the Pyatka tributary biotope (higher locomotor activity of the fish, frequent and fast darts for food, prolonged periods of feeding during the polar day, and greater availability of food) are the main factors contributing to the intensive growth and development of the salmon juveniles. This process is maintained by higher rates of metabolism (catabolism and anabolism of structural components) including proteolysis. The fingerlings inhabiting the Pyatka tributary demonstrated a relatively higher activity of intracellular proteolytic enzymes (cysteine-dependent and collagenolytic), indicating a higher rate of intracellular protein metabolism. It could be expected that this differentiation in fingerlings continues in further differences between the juveniles, ultimately resulting in different smoltification ages.

\section{Acknowledgements}

Biochemical studies were funded by the Russian Science Foundation under project No. 14-24-00102: 'Salmonids of northwest Russia: ecological biochemical mechanisms of early development'. The studies of the nomadic movements of the migratory behaviour of young salmon were supported by the Russian Science Foundation under project No. 14-14-01171: 'Relationship between migrations and morphogenesis in juvenile fish and lampreys'. Biochemical studies were carried out using the facilities of the Equipment Sharing Centre of the Institute of Biology, Karelian Research Centre RAS.

\section{Supplementary material}

To view supplementary material for this article, please visit https://doi.org/10.1017/S003224741600084X

\section{References}

Attaix, D., Combaret, L. and Taillandier, D. 1999. Mechanisms and regulation in protein degradation. Purdue University Press, 51-67. (Proceedings of the 8th International Symposium on Protein Metabolism and Nutrition. West Lafayette, IN)
Barrett, A. and Heath, M. 1977. Lysosomal enzymes. In Dingle, J., ed. Lysosomes: a laboratory handbook. Amsterdam: Elsevier, 19-27.

Baryshev, I.A., Veselov, A.E., Zubchenko, A.V. and other. 2005. Forage reserve of the Atlantic salmon in the basin of river Varzuga. In Vorobjeva, N.K., Nikenev, V.K. and Karasev, A.B., eds. Biology, reproduction and status of the stocks of anadromous and freshwater fishes of the Kola Peninsula. Murmansk: PINRO Press, 21-30.

Bohley, P. 1987. Intracellular proteolysis. In Brocklehurst, K. and Neuberger, A., eds. Hydrolytic enzymes. Amsterdam: Elsevier, 307-332.

Bondareva, L.A., Nemova, N.N. and Kaivarainen, E.I. 2006. Intracellular $\mathrm{Ca}_{2}^{+}$-dependent proteolytic system in animals. Moscow: Nauka.

Bradford, M. 1976. A rapid and sensitive method for the quantitation of microgram quantities of protein utilizing the principle of protein-dye binding. Analytical Biochemistry, 72, 248-254.

Cottin, P., Brustis, J. and Poussard, S. 1994. $\mathrm{Ca}^{2+}$-dependent proteinases (calpains) and muscle cell differentiation. Biochimica et Biophysica Acta, 1223, 170-178.

Eherington, D.J. and Evans, P.J. 1977. The action of cathepsin B and collagenolytic cathepsin in the degradation of collagen. Acta Biologica et Medica Germanica, 36, 1555-1563.

Jaescke, J. 1975. Zur routinemabigen bestimmung des freien hydroxyprolin in pflerdeserum: methodic und normalwerte. ZBL Veterinarmed, 22, 89-101.

Johnston, I., Bower, N. and Macquun, D. 2011. Growth and the regulation of myotomal muscle mass in teleost fish. Journal of Experimental Biology, 214, 1617-1628.

Kazakov, R.V., Kuz'min, O.G, Shustov, Y.A. and other. 1992. Atlantic salmon of Varzuga River. Saint-Peterburg: Gidrometeoizdat.

Konstantinov, A.S., Pushkar', V.Y.A., Zdanovich, V.V. and other. 2007. The magnitude of change and contingency growth parameters and energy of fish caused by temperature oscillations. MSU Vestnik, 16, 22-27.

Lysenko, L.A. and Nemova, N.N. 2012. Molecular evolution within protease family C2, or calpains. In Pravin, T., ed. Protein engineering. Kaumaya: Intech, 119-144.

Lysenko, L.A., Kantserova, N.P., Krupnova, M.Y. and others. 2015. Intracellular protein degradation in the development of the Atlantic salmon Salmo salar L. Russian Journal of Bioorganic Chemistry, 41, 645-651.

Matsuda, K. and Misaka, E. 1974. Studies on cathepsin D of rat liver lysosomes. I. Purification and multiple form. Journal of Biochemistry, 76, 639-649.

Mizote, A., Okamoto, S. and Iwao, Y. 1999. Activation of Xenopus eggs by proteases: possible involvement of a sperm protease in fertilization. Developmental Biology, 208, 79-92.

Mommsen, T.P. 2001. Paradigms of growth in fish. Comparative Biochemistry and Physiology - Biochemistry and Molecular Biology, B129, 207-219

Mommsen, T.P. 2004. Salmon spawning migration and muscle protein metabolism: the August Krogh principle at work. Comparative Biochemistry and Physiology - Biochemistry and Molecular Biology, B139, 383-400.

Murachi, T., Hatanaka, M., Yasumoto, Y. and other. 1981. A quantitative distribution study on calpain and calpastatin in rat tissues and cells. International Journal of Biochemistry, 2 , 651-658.

Murzina, S.A., Nefedova, Z.A., Veselov, A.E. and others. 2014. Changes in fatty acid composition during embryogenesis and in young age groups $(0+)$ of Atlantic salmon Salmo salar L. The role of rheotactic behavior and lipid composition of fry in the formation of phenotypic groups of salmon in large Arctic 
rivers. In Woo, P.T.K., Noakes, D.J., eds. Salmon: biology, ecological impacts and economic importance. New York, NY: Nova Science Publishers, 47-67.

Nemova, N.N., Kaivairainen, E.I., Nefedova, Z.A. and other. 2014. Calcium-dependent proteases (calpains) in fingerlings $(0+)$ of Atlantic salmon (Salmo salar L.) from two biotopes of Varzuga River, Proceedings of the Petrozavodsk State University, 145, 7-12.

Overturf, K. and Gaylord, T. 2009. Determination of relative protein degradation activity at different life stages in rainbow trout (Oncorhynchus mykiss). Comparative Biochemistry and Physiology - Biochemistry and Molecular Biology, B152, 150-160.

Pavlov, D.S. 1979. Biological basis of fish behavior in the control of water flow. Moscow: Nauka.

Pavlov, D.S., Meshcheryakova, O.V., Veselov, A.E. and others. 2007. Indicators of energy metabolism in juvenile Atlantic salmon (Salmo salar L.), living in the main channel and tributary Varzuga (Kola Peninsula). Journal of Ichthyology, 47, 819-826.

Pavlov, D.S., Nefedova, Z.A., Veselov, A.E. and others. 2008. Lipid status of fingerlings of the Atlantic salmon Salmo salar from different microbiotopes of the Varzuga River. Journal of Ichthyology, 48, 648-654.

Reddy, G. and Enwemeka, C. 1996. A simplified method for the analysis of hydroxyproline in biological tissues. Clinical Biochemistry, 29, 225-229

Salem, M., Kenney, B., Rexroad, C. and Yao, J. 2006. Molecular characterization of muscle atrophy and proteolysis associated with spawning in rainbow trout. Comparative Biochemistry and Physiology - Genomics and Proteomics, D1, 227237.

Salem, M., Nath, J., Rexroad, C. and others. 2005. Identification and molecular characterization of the rainbow trout calpains (Capn1 and Capn2): their expression in muscle wasting during starvation. Comparative Biochemistry and Physiology - Biochemistry and Molecular Biology, B140, 63-71.

Sandri, M. 2010. Autophagy in skeletal muscle. FEBS Letters, 584, 1411-1416.

Seebacher, F., Pollard, S.R. and James, R.S. 2012. How well do muscle biomechanics predict whole-animal locomotor performance? The role of $\mathrm{Ca}^{2+}$ handling. Journal of Experimental Biology, 215, 1847-1853.

Seiliez, I., Dias, K. and Cleveland, B. 2014. Contribution of the autophagy-lysosomal and ubiquitin-proteasomal proteolytic systems to total proteolysis in rainbow trout (Oncorhynchus mykiss) myotubes. American Journal of Physiology - Regulatory, Integrative and Comparative Physiology, 307, 13301337.

Seiliez, I., Gabillard, J.C., Riflade, M. and others. 2012. Amino acids downregulate the expression of several autophagyrelated genes in rainbow trout myoblasts. Autophagy, 8, 364375.

Shustov, Y.A. 1983. Ecology of juvenile Atlantic salmon. Petrozavodsk: Karelia.

Sorimachi, H. and Suzuki, K. 2001. The structure of calpains. Journal of Biochemistry, 129, 653-664.

Tompa, P., Emori, Y., Sorimachi, H. and others. 2001. Domain III of calpain is a $\mathrm{Ca}^{2+}$-regulated phospholipid-binding domain. Biochemical and Biophysical Research Communications, 280, 1333-1339.

Torrissen, K.R. 2014. Atlantic salmon Salmo salar L.: genetic variations in protein metabolism and growth. In Woo, P.T.K. and Noakes, D.J., eds. Salmon: biology, ecological impacts and economic importance. New York, NY: Nova Science Publishers, 85-119.

Valente, L., Moutou, K., Conceição, L. and others. 2013. What determines growth potential and juvenile quality of farmed fish species? Reviews in Aquaculture, 5, S168-S193.

Veselov, A.E. and Kalyuzhin, S.M. 2001. Ecology, behavior and distribution of juvenile Atlantic salmon. Petrozavodsk: Karelia.

Veselov, A.E., Kazakov, R.V., Sysoyeva, M.I. and other. 1998. Ontogenesis of reotactic and optomotor responses of juvenile Atlantic salmon. Aquaculture, 168, 17-26.

Veselov, A.E., Zubchenko, A.V., Potutkin, A.G. and others. 2005. Spawning and nursery foundation of Varzuga river. In Vorobjeva, N.K., Nikenev, V.K. and Karasev, A.B., eds. Biology, reproduction and status of the stocks of anadromous and freshwater fishes of the Kola Peninsula. Murmansk: PINRO Press, 52-80.

Zippin, C. 1956. An evaluation of removal method of estimating animal populations. Biometrics, 12, 163-169. 